\title{
KOMPETENSI GURU SEBAGAI PROFESIONAL
}

\author{
Muhammad Rival \\ Email:2010128310001@mhs.ulm.ac.id \\ Program Studi Pendidikan Sejarah Fakultas Keguruan dan Ilmu Pendidikan \\ Universitas Lambung Mangkurat \\ Banjarmasin
}

\begin{abstract}
Abstrak
Profesi merupakan suatu pekerjaan yang hanya diperoleh apabila memenuhi syarat yaitu memiliki keahlian khusus, kemampuan khusus, diperoleh dari proses pendidikan, kode etik, dan organisasi, seorang guru dapat dikatakan sebagai profesi karena memenuhi syarat tersebut dan dapat digoongkan sebagai profesi. Dalam pengembangannya seorang guru harus memiliki kompetensi khusus untuk dapat dikatakan sebgai professional. Dengan pengembangan kualitas dan mutu guru yang professional dapat memajukan pendidikan di Indonesia
\end{abstract}

\section{PENDAHULUAN}

Secara etimologi profesi berasal dari kata profession (inggris) yang berasal dari bahasa Latin profesus yang memiliki arti "mampu atau ahli dalam suatu bentuk pekerjaan". Profesi dimaknai sebagai suatu jabatan atau dalam pekerjaan yang mempunyai dan menuntut keahlian khusus berdasarkan pada bidang keahliannya tersebut, keahlian ini dapat diperoleh melalui proses pendidikan dan latihan tertentu, memenuhi persyaratan khusus memiliki tanggung jawab dan kode etik tertentu bedasarkan profesinya. Pekerjaan yang bersifat profesional berbeda dengan pekerjaan lainnya karena suatu profesi memerlukan kemampuan dan keahlian khusus dalam melaksanakan profesinya. Artinya suatu pekerjaan atau jabatan yang disebut profesi tidak dapat dipegang oleh sembarang orang, tetapi memerlukan persiapan melalui pendidikan dan pelatihan secara khusus (Musriadi, 2016: 27-30). Secara umum suatu pekerjaan dapat dikatakan sebagai profesi apabila dapat memenuhi kriteria antara lain memiliki keahlian khusus, memiliki kode etik, memiliki organisasi profesi, diakui masyarakat, sebagai panggilan hidup, dan memiliki kecakapan diagnostic atau kemampuan memperkirakan penyebab dan atau akibat berdasarkan gejala atau ciri-ciri tertentu, menganalisis, serta kemampuan untuk menentukan tindakan yang tepat untuk menangani atau menyelesaikan permasalahan, serta memiliki klien yang jelas.

Guru merupakan sebuah profesi diamna untuk menjadi seorang guru memerlukan keahlian khusus dalam menjalankan tugasnya dan tidak dapat dilakukan diluar daribidang pendidikan serta profesi guru menuhi dari kriteria sebagai pekerjaan yang dapat dikatakan sebagai profesi.. Seorang guru merupakan seorang yang ditugaskan dalam membimbing 
atau memberi bantuan kepada peserta didik dalam perkembangan baik secara jasmani maupun rohaninya agar mencapai tingkat kedewasaan. Seorang guru dapat dikatakan sebagai profesi yang artinya jabatan tersebut memerlukan suatu keahlian yang didapatkan melalui proses pendidikan yang lebih khusus sesuai dengan kriteria perofesi sehingga memiliki wawasan dan keahlian yang mempuni serta memenuhi syarat perofesi sebagai guru.

\section{PERAN GURU SEBAGAI SEBUAH PROFESI}

Dalam menjalankan perannya seorang guru dapat dikatakan sebagai profesi. dalam pendidikan seorang guru dituntut untuk memiliki suatu keahlian tertentu baik dalam mengajar, mengelola kelas, dan merancang proses pembelajaran. berdasarkan syarat umum profesi, seorang guru dapat dikatakan sebagai profesi dimana guru memenuhi setiap peryaratan tersebut dan dapat digolongkan sebagai pekerjaan profesi antara lain seorang guru memiliki spesialisasi ilmu yang khusus dengan melalui proses pendidikan. dalam PP No.19 2005 tentang standar Nasional pendidikan, guru harus memiliki sertifikasi profesi guru untuk dapat bekerja sebagai guru disamping kuslifikasi akademil minimal yaitu sarjanaatau diploma IV. kemudian dalam menjalani profesi seorang guru juga memiliki kode etik dimana kode etik merupakan pedoman moral bagi seorang guru dalam menjalankan tugasnya sebagai seorang yang profesional. profesi guru memiliki organisasi sebgai wadah untuk membangun profesi guru melalui sharing informasi dan komunikasi setiap anggota profesi. sebagai syarat profesi pengakuan masyarakat dapat diperoleh melalui peran yang diberikan oleh guru dan mendapatkan apresiasi dari masyarakat berupa sebuah pengakuan terhadapkeberadaan seorang guru dalam mendidik peserta didik. bekerja pada profesi guru memiliki pengabdian terhadap dunia pendidikan sebagai panggilan hidup dan mendalami keilmuan pada bidang suatu profesi tersebut, sehingga semakin lama dalam menjalankan profesi tersebut maka keahlian tersebut akan semkin meningkat. Seorang guru dapat memperkirakan penyebaab serta akibat dalam proses atau pelaksanaan pendidikan sehingga dapat diketahui bagaimana cara pemecahan masalahnya bak berupa gejala dan ciri-ciri dari sebab akibat tersebut. Seorang guru juga memiliki klien, sangat jelas bahwa klien profesi guru adalah peserta didik yang merupakna tujuan utama dalam pendidikan untuk dapat mencerdaskan dan mengembangkan kemampuan yang dimiliki oleh peserta didik sebagai bekal dimasa yang akan datang dan kehidupan yang sesungguhnya untuk bekal dimasa yang akan datang.

Setiap pekerjaan tentu memiliki peran termasuk pada profesi sebagai seorang guru. Dalam dunia pendidikan guru memiliki peranan yang besar dalam membangun dan melaksanakan proses pendidikan di Indonesia. Hal ini dikarenakan guru memiliki peranan langsung dan berhadapan dengan peserta didik untuk mentranfer ilmu pengetahuan dan teknologi sekaligus dalam mendidik dan membimbing karakter, minat dan bakat peserta didik dengan nilai-nilai yang positif yang di ajarkan. Berdasarkan undang-Undang No. 14 
Tahun 2005, dikataka bahwa pendidik yang profesional memiliki tugas utama yaitu mengajar, membimbing, mendidik, mengarahkan, melatih, menilai dan mengevaluasi peserta didik. Artinya profesi guru memiliki hak dan kewajiban dimana dalam pelaksanaannya berdasarkan undang-undang No.14 Tahun 2005 tentang guru dan dosen bagian kedua pasal 14 tentang hak dan kewajiban guru yang dimana berisi beberapa poin tentang hakdan kewajiban itu sendiri antara lain memperoleh penghasilan untuk kebutuhan hidup, mendapatkan penghargaan atas prestasi kerja, mendapat perlindungan dalam bekerja, dapat memningkatkan kompetensi diri, dendapatkan dan mengguanakan sarana dan prasarana dalam pembelajaran guna meningkatkan mutu guru dalam pembelajaran, memberikan penilaian serta keputusan dalam kelulusan ataupun penghargaan serta sanksi kepada peserta didik sesuai dengan kode etik dan peraturan yang berlaku secara undangundang, mendapatkan perlindungan dan rasa aman dalam menjalankan tugasnya, memiliki kebebasan dalam berorganisasi, hak berserikat dalam organisasi profesi, dapat mengembangkan dan meningkatkan mutu akademik serta kompetensi, mendapatkan pelatihan dan pengembangan.

Dalam menjalankan tugas sebagai profesi guru, seorang guru berhak untuk mendapatkan apa yang memang berhak didapatkan berdasarkan kode etik dan peraturan yang berlaku secara perundang undangan yang meliputi hak hak yang telah disebutkan di atas sehingga hak tersebut dapat memberikan rasa aman kepada guru dalam menjalankan tugasnya sebagai professional dan dapat berperan dalam partisipasi membangun serta mengembangakn pendidikan di Indonesia.

Selain hak yang dimiliki oleh profesi guru, profesi guru juga memiliki kewajiban yang harus dilaksanakan sebagai professional dimana dalam melaksanakan tugas sebagai professional dituangkan dalam Undang-Undang No. Tahun 2005 padal 20 tentang guru dan dosen dimana guru mrmiliki kewajiban yang meliputi merencakan, melaksanakan serta mengevaluasi dalam proses pembelajaran, mengembangakan dan meningkatkan kualitas penddikan dalam prodes pembelajaran baik pada segi akademik maupun non akademik, seorang guru haruslah memiliki sifat yang objektif dan tidak bersifat diskriminatif atas dasar apapun dalam artian memberlakukan semua peserta didik itu sama sesuai dengan kebutuhan peserta didik itu sendiri, seorang guru juga wajib untuk mentaati peraturan Undang-Undangan, hukum dank ode etik yang berlaku, serta nilai-nilai keagamaan, dalam menjalankan profesinya seorang guru juga harus dapat memberikan rasa kebangsaan yang beik kepada peserta didik sehingga dapat memupuk rasa persatuan dan kesatuan bangsa.

\section{GURU INDONESIA DAN TANTANGAN PROFESIONALISME}

Dalam memajukan pendidikan di Indoensia peran guru merupakan unsur yang paling berpengaruh dalam dunia pendidikan, karena guru adalah orang-orang yang selalu berhadapan dan berinteraksi langsung kepada peserta didik guna menjalankan kewajiban dan memberikan pendidikan sehingga proses belajar dan pembelajaran dapat berlangsung 
dengan baik. Dalam melaksanakan kewajiban sebagai seorang guru tentu harus memiliki sikap dan kompetensi yang professional guru guna meningkatkan dan memajukan pendidikan di Indoensia sikap professional tersebut meliputi beberapa bagian-bagian yang menjadi dasar dalam sikap professional profesi guru yang meliputi kemampan merencanakan pembelajaran, Kemampuan melaksanakan pembelajaran, Kemampuan dalam bersosialisasi kepada peserta didik, kemampuan dalam menguasai keahlian pada bidangnya, bertanggung jawab, memiliki rasa kesejawatan.

Komptensi professional merupakan tindakan berupa kemampuan dalam mengendalikan wewenang suatu profesi dengan rasa tanggung jawab. menurutDepdibud (1980) terdapat 10 kemampuan dasar guru meliputi pemahamnakonsep dan bahan ajar, pengelolaan program belajar, mengelola kelas, penggunaan sumber belajar, menguasai landasan pendidikan, mengelola kegiatan belajar dan mengajar, apresiasi berupa penilaian,memahami fungsi bimbingan dan penyuluhan, penyelenggaraan administrasi di sekolah. Dan memahami prinsip-prinsip danb memanfaatkan hasil penelitian untuk meningkatkan mutu $\mathrm{m}$ dalam pengajaran.

Dalam pengembangan kompetensi guru terdapat tiga aspek yang harus dikemangkan guna meningkatkan mutu guru. Pengetahuan (knowledge), seorang guru harus memiliki pengetahuan terkait bidang yang ditekuninya yang didapat melalui proses mempelajar, pengalaman, dan analisis terhadap apa yang telah dipelajari sehingga pengetahuan seorang guru semakin meningkat untuk menjadikan seorang guru yang professiona. Kemampuan (Ability)dipelajari melalui potensi bakat dan pembelajaran hal ini harus dikembangan oleh seorang guru agar proses transefer ilmu dapat bejalan dengan baik dan sesuai dengan apa yang diharapkan. Keterampilan (skill) seorang guru dituntut untuk memiliki terampilan khusus baik itu pada proses mengajar, memimpin kelas, dan membimbing. Sikap diri (attitude) seorang guru itu diguguh dan dituru, maka menjadi seorang guru harus memiliki sikap yang baik agar menjadi tauladan bagi peserta didiknya. Kebiasaan (habit) kebiasaan yang baik harus dimiliki oleh serang guru berupa kebiasaan yang positif karena pada kebiasaan ini lah secara tidak langsung maupun langsung akan mnajdi contoh pada peserta didiknya.

Pedagogik adalah teori mendidik yang mempersoalkan apa dan bagaimana mendidik sebaik-baiknya (Suardi, 1979:113). Dalam menutun peserta didik perlu adanya metode yang tepat dalam pelaksanaanya mempunyai kemampuan dalam memahami peserta didik baik darikarakteer maupun prinsip perkembangannya, merancang pembelajaran dengan media apapun, kemampuan melaksanakan pembelajaran, kemampuan mengevaluasi, dan kemampuan mengembangkan.

\section{SIMPULAN}

Profesi merupakan suatu pekerjaan yang hanya dapat diperoleh melalui beberapa syarat yang harus dipenuhi untuk dapat dikatakan profesi yaitu mrmiliki spesialis ilmu, kode etik, 
organisasi, diakui masyarakat, panggilan hidup, dan kecakapan diagnostic, serta klien yang jelas. Guru dapat dikatakan sebagai profesi karena memenuhi dari semua persyaratan tersebut. Menurut Undang-undang RI No.14 Tahun 2005 tentang guru dan dosen bahwa guru adalah pendidik yang memiliki tugas melatih, menilai, dan mengevaluasi peserta didik. Untuk meningkatkan dan memajukan pendidikan di Indonesia perlu adanya sikap profesionalisme seorang guru untuk meningkatkan kualitas guru itu sendiri sehingga berdampak paa kualitas pendidikan di Indonesia. Kualitas tersebut yang harus dikembangkan meliputi merencanakan pembelajaran, mengembangkn dan meningkatkan kualitas akademik, bertinfak objektif, taan akan aturan, memelihara dan memupuk persatuan dan kesatuan bangsa.

\section{REFERENSI}

Efendi, I., Prawitasari, M., \& Susanto, H. (2021). Implementasi Penilaian Pembelajaran Pada Kurikulum 2013 Mata Pelajaran Sejarah. Prabayaksa: Journal of History Education, 1(1), 21-25.

Susanto, H. (2020). Profesi Keguruan. Banjarmasin: FKIP Universitas Lambung Mangkurat.

Susanto, H., \& Akmal, H. (2018). Efektivitas Penggunaan Aplikasi Pembelajaran Berbasis Mobile Smartphone Sebagai Media Pengenalan Sejarah Lokal Masa Revolusi Fisik Di Kalimantan Selatan Pada Siswa Sekolah Menengah Atas. HISTORIA: Jurnal Program Studi Pendidikan Sejarah, 6(2), 197-206.

Susanto, H., Irmawati, I., Akmal, H., \& Abbas, E. W. (2021). Media Film Dokumenter Masuknya Islam Ke Nusantara dan Pengaruhnya Terhadap Keterampilan Berpikir Kritis Siswa. HISTORIA: Jurnal Program Studi Pendidikan Sejarah, 9(1).

Syaharuddin, S., \& Susanto, H. (2019). Sejarah Pendidikan Indonesia (Era Pra Kolonialisme Nusantara sampai Reformasi). Banjarmasin: FKIP Universitas Lambung Mangkurat.

Gaffar, M. F. (2017). Guru Sebagai Profesi. Jurnal Administrasi Pendidikan, 5(1).

Fitriana, S. (2008). Pentingnya Profesionalisme Guru Dalam Meningkatkan Kualitas Pendidikan. MAJALAH LONTAR, 22(2). 